Research article

\title{
MOLECULAR STUDY OF THE PREVALENCE OF BRUCELLA ABORTUS AND BRUCELLA MELITENSIS IN THE BLOOD AND LYMPH NODE SAMPLES OF SLAUGHTERED CAMELS BY POLYMERASE CHAIN REACTION (PCR) IN IRAN
}

\author{
KHAMESIPOUR Faham ${ }^{1,2 *}$, RAHIMI Ebrahim ${ }^{3}$, SHAKERIAN Amir ${ }^{3}$, DOOSTI \\ Abbas $^{4}$, MOMTAZ Hassan ${ }^{5}$ \\ ${ }^{1}$ Faculty of Veterinary Medicine, Shahrekord Branch, Islamic Azad University, Shahrekord, Iran; \\ ${ }^{2}$ Young Researchers and Elite Club, Shahrekord Branch, Islamic Azad University, Shahrekord, \\ Iran; ${ }^{3}$ Department of Food Hygiene, Faculty of Veterinary Medicine, Shahrekord Branch, \\ Islamic Azad University, Shahrekord, Iran; ${ }^{4}$ Biotechnology Research Center, Shahrekord Branch, \\ Islamic Azad University, Shahrekord, Iran; ${ }^{5}$ Department of Microbiology, Faculty of Veterinary \\ Medicine, Shahrekord Branch, Islamic Azad University, Shahrekord, Iran
}

(Received 02. February; Accepted 24. April 2014)

Brucellosis is a zoonotic disease which is characterized by reduced fertility and abortion in several species of animals, as well as humans. Camel brucellosis is caused by Brucella abortus and Brucella melitensis. To overcome the limitations posed by other techniques such as culture and serology, a sensitive technique (PCR) was employed for the detection of brucellosis in 123 camels. Findings from this PCR study indicated a total of $11.38 \%$ of blood samples as positive for Brucella spp. and $13.01 \%$ of the lymph node samples were positive for Brucella spp. In this study, 5 out of $123(4.065 \%)$ and 3 out of $123(2.439 \%)$ camel blood samples were positive for B. abortus and B. melitensis, respectively. Also, 4 out of $123(3.252 \%)$ and 2 out of $123(1.626 \%)$ camel lymph node samples were positive for B. abortus and B. melitensis, respectively. Young camels were the most commonly infected age group, while adult camels were the less often infected age group. Also, higher prevalence of brucellosis was observed in female camels. These results have indicated that PCR is a sensitive technique which could be used as a confirmatory test for the detection of brucellosis in live camels, at the same time with the lowest risk of infection of laboratory personnel. The obtained results suggest that control and eradication programs for Brucella spp. infection seem to be necessary in camels. Our findings support the power of PCR test for Brucella spp. detection in the blood and lymph node samples and it could be easily used for routine diagnosis.

Key words: camel, brucellosis, zoonosis, blood, lymph nodes, Polymerase Chain Reaction (PCR)

\section{INTRODUCTION}

Camels are the toughest animal species for production and survival under harsh environmental conditions and have been considered an aid to man for thousands

* Corresponding author: e-mail: Dr_Faham@yahoo.com; F.Khamesipour@iaushk.ac.ir 
of years. Camels have a high money-based value by providing meat, milk, wool, as well as transportation and labor. The camel is a domestic mammal which due to its physiological attributes is suitable for use in climatic extremes. Diseases, poor nutrition, and traditional management systems have restricted their full utilization [1,2]. Even though several pastoral groups and communities all over the world depend on camels for their livelihood, the health status of camels has not yet received proper attention from researchers and scientists.

The camel is a domestic animal that may be infected with Brucella. Camel brucellosis is caused by Gram-negative coccobacilli bacteria of the genus Brucella and is characterized by lesions of lymph nodes and joint capsules, orchitis and epididymitis, inflammation of the uterus, abortion, and reduced fertility. Also, many infected camels are silent carriers of brucellosis [1-3]. Brucellosis remains to be the main zoonosis and is found globally. Furthermore, it seems that the issue of Brucella in the camel has potentially important implications for public health and implementation of brucellosis control programs. Primarily, the camel may act as a reservoir for the dissemination of contaminated secretions to other domestic animals and humans. Secondly, in several nations, no formal surveillance and eradication programs for camel brucellosis have been proposed [2,3]. In some developed nations brucellosis is well controlled, however in Africa, Asia, South and Central America, and the Middle East, the clinical disease is still present among individual owners of camels. In Iran, B. melitensis and B. abortus are an overall public problem [4].

The genus Brucella consists of 8 species. Camels are highly susceptible to Brucella abortus (B. abortus), and Brucella melitensis (B. melitensis) [1], but camels are not known to be primary hosts of Brucella. Thus, camel brucellosis depends on the Brucella species prevalent in other animal species sharing the same habitats, and on husbandry methods [1]. Moreover, the main species affecting humans are B. abortus and B. melitensis, which cause brucellosis, also known as Malta fever [4].

Consumption of Brucella infected food e.g. milk and meat from camels has led to a high number of human brucellosis cases and is a serious public health issue. The situation is even more grave as farmers from rural areas think that raw camel milk has a healing effect on the digestive system [1].

The eradication of brucellosis is an essential step to control the disease in humans [2]. Cattle, goat, sheep, camels and other livestock may be infected and transmit the disease to human populations. Moreover, pastoralists in endemic areas are at high risk of infection by Brucella species [5]. Brucellosis of camels in Iran has been studied mainly by serological methods, without isolation of the causative agent [2].

Currently, diagnosis of brucellosis is based on serological and microbiological tests. Serological methods are not always sensitive or specific and are laborious (little sensitivity), time-consuming, pose a risk for infection, and can generate discordant results $[1,2]$.

Isolation and identification are the most reliable techniques in the diagnosis of brucellosis, even though not always successful, and represent a major infection 
risk for technicians [2]. Microbial culture may be used for several suspected cases, nonetheless is not used for surveying the disease in the camel populations [2,7]. Also, with these two methods, species cannot be differentiated from each other [4]. In consequence, over the last few years progress has been made in applying new molecular and genetic diagnostic methods to improve the diagnosis of brucellosis and nucleic acid amplification techniques might circumvent the diagnostic window being presented before production of specific antibodies $[1,2,8]$. One of these methods, the polymerase chain reaction (PCR) is a sensitive, fast, and relatively cheap method and is mainly useful in the detection of Brucella DNA in tissues and body fluids contaminated with non-viable or a low number of Brucella [2]. There are few publications on using PCR in the detection of camel brucellosis [2,7].

The objective of this study was to determining the prevalence of Brucella spp. in lymph nodes and blood samples from camels by using PCR method and to identify potential risk factors for infection. PCR is a rapid and simple technique capable of specifically detecting Brucella infection in camels.

\section{MATERIALS AND METHODS}

\section{Location and sampling}

The Najaf-Abad region is located in the west of Isfahan province, Center of Iran. Blood $(n=123)$ and lymph node $(n=123)$ samples were collected from 123 camels from both sexes and different ages of camels in Najaf-Abad's abattoir in Isfahan province (Iran) for a period of 3 months (from March 2013 to May 2013). The camels (Camelus dromedaries) were apparently healthy at the time of slaughter and none were previously immunized against Brucella spp. Also, these animals were imported from Pakistan at the end of 2012 and at the beginning of 2013 (the camels were not serologically tested for brucellosis).

All samples were collected under sterile hygienic conditions. From each animal, $10 \mathrm{ml}$ of whole blood (with anticoagulant) was aseptically taken and immediately divided into $10 \mu \mathrm{l}$ aliquots in tubes containing EDTA and used for PCR. After slaughtering the animals, lymphoid tissue was sampled from the subscapular lymph nodes and immediately placed in sterile containers. All samples were kept on ice and transported to the Biotechnology Research Centre of Islamic Azad University of Shahrekord laboratory. Blood and lymph tissue samples were kept frozen $\left(-20^{\circ} \mathrm{C}\right)$ until analysis.

\section{DNA extraction from blood and lymph tissue samples}

DNA from the 246 blood and lymph tissue samples was extracted using the CinnaGen DNA extraction kit ${ }^{\mathrm{TM}}$ (Cinnagen, Tehran, Iran) according to the instructions of the manufacturer. Total DNA was measured at $260 \mathrm{~nm}$ according to the method described by Sambrook and Russell [9]. 


\section{DNA amplification and detection of PCR products}

The PCR reaction mixtures were placed in a Corbett Palmcycler (Corbett Research, Australia). Genus-specific PCR primers 1 (Bru-F: 5' CTATTATCCGATTGGTGGTCTG 3'and Bru-R: 5' GGTAAAGCGTCGCCAGAAGG 3') were used to amplify a $245 \mathrm{bp}$ for the detection of Brucella spp. [4], and primers 2 (Ba-F: 5' GACGAACGGAATTT'TTCCAATCCC 3' and RR: 5' TGCCGATCACTTAAGGGCCTTCAT 3') were used to amplify a 494 bp for Brucella abortus [10] and primers 3 (Bm-F: 5' AAATCGCGTCCTTGCTGGTCTGA 3' and RR: 5' TGCCGATCACTTAAGGGCCTTCAT 3') to amplify a 734 bp for Brucella melitensis [10].

PCR was carried out in a total volume of $25 \mu \mathrm{l}$, using $50 \mathrm{mM} \mathrm{KCl}, 10 \mathrm{mM}$ Tris$\mathrm{HCl}(\mathrm{pH} 8), 1.5 \mathrm{mM} \mathrm{MgCl}, 0.2 \mathrm{mM}$ each of the four deoxynucleotide triphosphate and $0.05 \mathrm{IU}$ of Taq polymerase (Roche applied science, Germany), $0.4 \mathrm{mM}$ of each primer, and $2 \mu \mathrm{l}$ template DNA.

The amplification was performed in a DNA thermal cycler at a denaturation temperature of $95^{\circ} \mathrm{C}$ for $5 \mathrm{~min}$; followed by 35 cycles at $94^{\circ} \mathrm{C}$ for $45 \mathrm{~s}, 64.9^{\circ} \mathrm{C}$ for $1 \mathrm{~min}$, and $72^{\circ} \mathrm{C}$ for $1 \mathrm{~min}$ and one final extension at $72^{\circ} \mathrm{C}$ for $7 \mathrm{~min}$, with a final hold at $4^{\circ} \mathrm{C}$ in a DNA thermal cycler (Mastercycler Gradient, Eppendorf, Hamburg, Germany).

Distilled water instead of template DNA was routinely used as the negative control in each PCR together with the DNA samples to eliminate the effect of contamination. Positive controls with genomic DNA of Brucella were included in each run to detect any amplicon contamination or amplification failure.

\section{Electrophoresis}

The PCR products were loaded in a $1 \%(\mathrm{w} / \mathrm{v})$ agarose gel containing $1 \times$ TBE buffer (100 mMTris- $\mathrm{HCl}$ (pH 8), $90 \mathrm{mM}$ boric acid, and $1 \mathrm{mM} \mathrm{Na} \mathrm{EDDTA}_{2}$ ), stained with an ethidium bromide solution $(0.5 \mu \mathrm{g} / \mathrm{ml}$ ) and a DNA ladder (Fermentas Co., Germany) used to detect the molecular weight of observed bands and visualized under UV light. Also, images were obtained in UVIdoc gel documentation systems (Uvitec, UK).

\section{Statistical analysis}

Data were transferred to a Microsoft Excel spreadsheet (Microsoft Corp., Redmond, WA, USA) for analysis. Using the Statistical Package for the Social Sciences (SPSS) 18.0 statistical software (SPSS Inc., Chicago, IL, USA).

\section{RESULTS}

In this study, blood and lymphoid tissue samples were collected from 123 camels and all of the samples were examined using PCR technique. The number of positive Brucella samples obtained from slaughtered camels is shown in Table 1. 


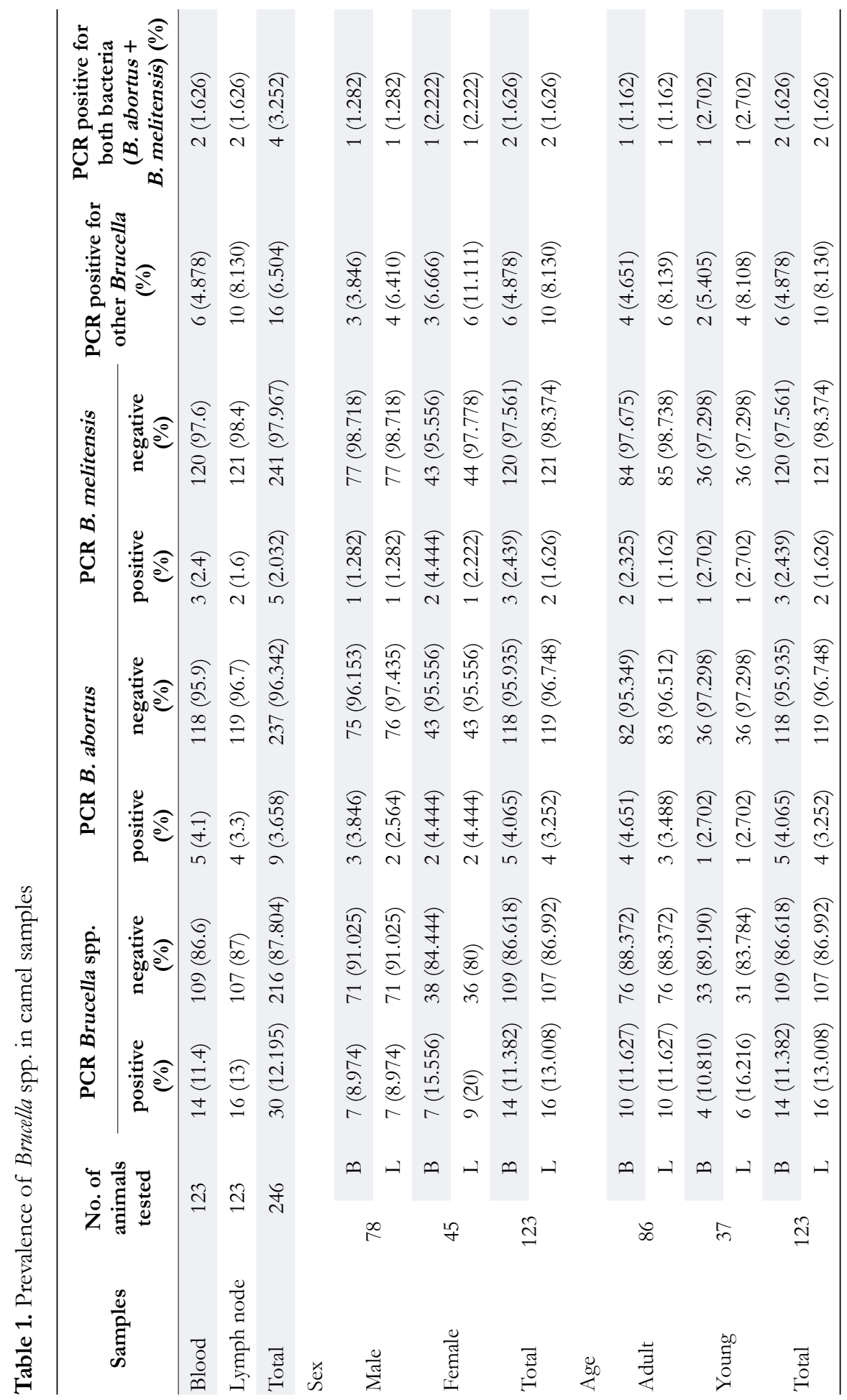


Findings from this study indicated that $11.38 \%$ blood samples were positive for Brucella spp. and $13.01 \%$ lymph node samples were positive for Brucella spp. by PCR method. In this study, 5 out of $123(4.065 \%)$ and 3 out of $123(2.439 \%)$ camel blood samples were positive for B. abortus and B. melitensis, respectively. Also, 4 out of $123(3.252 \%)$ and 2 out of $123(1.626 \%)$ camel lymph node samples were positive for B. abortus and B. melitensis, respectively. Moreover, 4.88\% camel blood samples and 8.13\% lymph node samples were positive for other Brucella species.

All samples (blood and lymph samples) were tested for Brucella spp. where a positive band had a 245 bp (Figure 1). Also samples were tested specifically for B. abortus and B. melitensis and the positive samples indicated a band size of 494 and 734, respectively (Figure 2).

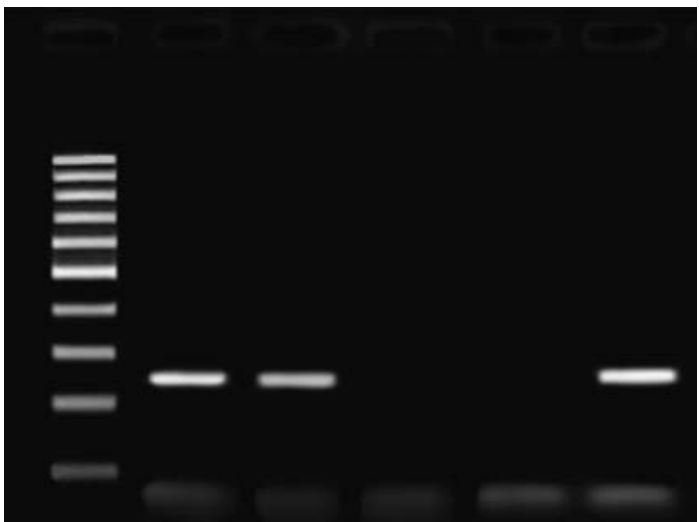

Figure 1. Ethidium bromide-stained agarose gel electrophoresis of PCR products (245 bp) for the detection of Brucella spp. in camel samples after PCR amplification.

Lane 1: 100 bp DNA ladder (Fermentas, Germany); lanes 2 and 3: Brucella in camel (lanes 2: Brucella in blood sample and lane 3: Brucella in lymph node sample); lanes 4: negative sample; lane 5: Negative control and lane 6 is the positive control.

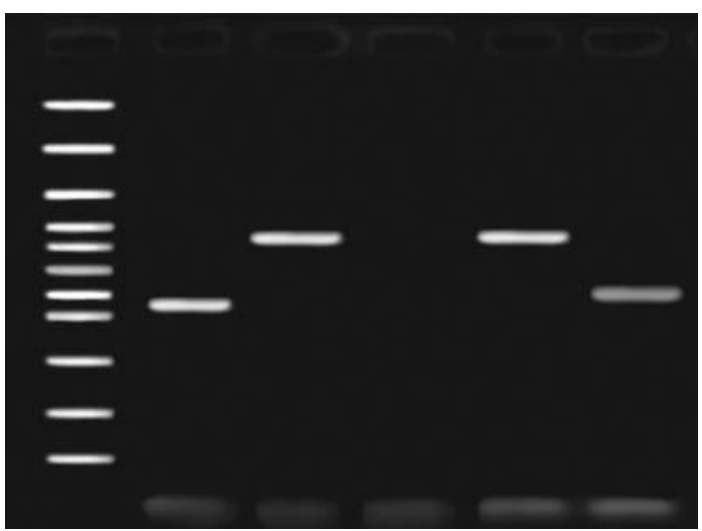

Figure 2. Ethidium bromide-stained agarose gel electrophoresis of PCR products (494 bp and $734 \mathrm{bp}$ ) for detection of B. abortus and B. melitensis in camel samples after PCR amplification. Lane 1: 100 bp DNA ladder (Fermentas, Germany); lanes 2 and 6: B. abortus in camel (lanes 2: B. abortus in blood sample and lane 6: $B$. abortus in lymph node sample); lanes 3 and 5: $B$. melitensis in camel (lanes 2: B. melitensis in blood sample and lane 6: B. melitensis in lymph node sample); lanes 4: Negative control. 


\section{DISCUSSION}

Camels are widespread and multipurpose animals in Iran; over 200,000 dromedary camels live in the arid and semiarid deserts of Iran [2]. However camel brucellosis has received little study, notwithstanding its importance in the transmission of Brucella to human beings. It is important for the reason that there is no worldwide programs for the control of camel brucellosis such as for example vaccination, testing, and slaughter of reactors.

To our data, although there are some reports on the detection of camel brucellosis in Iran and other parts of the world, this is the first time that PCR has been applied in the diagnosis of camel brucellosis (B. abortus and B. melitensis) and has obtained suitable results with good specificity. In future, an appropriate PCR technique could be used as a supplementary test for the identification and differentiation of Brucella in camels with the lowest risk of infection to laboratory personnel [2].

The camel plays very important socioeconomic roles and supports the survival of millions of people in the dry and semi dry zones of Africa and Asia [11]. Brucellosis is a serious zoonotic disease affecting man and all domestic animals including camels. It is considered as one of the greatest public health problems all over the world [2,11]. Brucellosis was reported in camels as early as 1931 [11], later, the disease has been reported from all camel-keeping nations [11].

Work-related acquired brucellosis is of special concern for public health due to the high risk of direct transmission from infected animals to persons being employed in animal husbandry. This exposed group includes veterinary clinicians, dairymen, slaughter men and herdsmen. Herdsmen are at the highest risk. The occupational exposure is high, especially in nations where herding of animals is still traditional and unscientific [11]. Through the development of commercial camel dairies in some nations, this disease should be considered because of its impact on human health. Regrettably, until now, there are no studies on eradication strategies or vaccination of camel brucellosis [11].

Since the discovery of brucellosis, many articles on investigations into brucellosis in camels, cattle, sheep and goats, and human beings have been published [4,12-17]. Serological evidence for Brucella infection in camels has been reported in Asia and Africa [18-20]. The isolation of Brucella spp. from internal organs (particularly lymph nodes, testes and vagina) has previously been done [3,4]. Isolation of B. melitensis and B. abortus from camels' milk has also been reported [11,21].

The prevalence of camel brucellosis from different nations may be attributed to changing husbandry and management practices, the number of affected camels, the virulence of the organisms, absence of veterinary service, presence of reactor animals in the area, lack of awareness about the disease in camels and continuous movement of infected camels into a camel herd [11]. Camels can be infected via the alimentary tract from contaminated feed or water, via the respiratory system with contaminated dust or droplets, and via the genital system from infected semen $[2,11]$. 
Malta fever caused by B. melitensis was detected in 30\% of camel milkers and handlers on a large camel farm in Riyadh, Saudi Arabia. The abortion rate on the farm, reached $12 \%$ and $B$. melitensis biovars 1, 2 and 3 were isolated from aborted camel fetuses [11]. Consequently, there is a real need for a cooperation between public health officials and veterinary officers to decrease the circulation of human brucellosis in endemic areas [22].

A number of researchers have used different serological tests (RBT, CFT, Serum Agglutination Test (SAT), Competitive Enzyme Linked Immunosorbent Assay (cELISA), Indirect Enzyme Linked Immunosorbent Assay (iELISA), and Mercaptoethanol test $(2 \mathrm{ME})$ for the finding of camel brucellosis $[7,23,24]$. Seroprevalence of camel brucellosis appear to follow two distinct patterns i.e. a low prevalence below $5 \%$ in nomadic or extensively kept camels and a high prevalence of $8-15 \%$ in camels kept intensively or semi intensively [3]. More-successful isolation of Brucella was reported from lymphoid tissues than any other organ [3].

B. melitensis was isolated from camels in many countries such as Iran, Libya and Saudi Arabia; B. abortus was isolated in Egypt, Kuwait and Sudan. It is likely that the tendency of Saudis to raise large flocks of sheep along with the camel herds contributed towards the spread of B. melitensis among camels [3]. Warsame et al., (2012) studied camel brucellosis and reported an overall seroprevalence of 1.5\% $(n=646)$ [19]. Teshome et al., (2003) reported camel brucellosis with a seroprevalence of $5.7 \%$ and $2.8 \%$ in Afar and Somali regions in Ethiopia [25]. The Tilahun et al., (2013) study showed a 2.43\% overall seroprevalence of camel brucellosis in Eastern Ethiopia [5].

High seroprevalence of camel brucellosis has been recorded in Sudan 30.5\% [26], in Darfur (Western Sudan) 23.8\% [27], in Jordan 19.4\% [28], and in Egypt 7.3\% [29]. Zewold and Haileselassie (2012) studies on brucellosis from 768 camel serum samples indicated $11.9 \%$ positive reactors for RBPT and 7.6\% for CFT [30].

Musa et al. (2008) reported a higher prevalence of brucellosis (23.8\%) from camels kept concurrently with other ruminant species; they recommended that cattle were the likely source infection for the camels as small ruminants were seronegative [27]. The seroprevalence of brucellosis was three to four-fold higher among adult camels than young ones and two-fold higher in females compared to males [3]. Human infection caused by Brucella from camels is known to happen typically through the consumption of raw milk [11].

Control of camel brucellosis should be a must for nations where camels are raised. Vaccination of uninfected animals is conventionally considered as the most effective and economical mean of defending farm animals against brucellosis [31].

The current research showed that the prevalence of camel brucellosis was low. Even though, prevalence of camel brucellosis is low, the positive animals may serve as future foci of infection, leading to low productivity, posing a public health risk and lowering the market value of camels. The low prevalence observed in the present research might be due to the low density of the camel population kept in a widely extended 
grazing land and the presence of several watering points in the river path of the valleys which reduce the concentration and close contact of camels. Moreover, the good practice of herders of timely culling non-conceiving females and removing aborted fetuses from the herds might have contributed to the situation.

These findings suggest that control and eradication programs for Brucella spp. infection in Iran should be taken into consideration. Our findings support the power of PCR testing for Brucella spp. detection in blood and lymph node samples and could be mainstreamed in routine diagnosis of brucellosis.

In conclusion, camels play a significant role in the epidemiology of brucellosis; the probability that brucellosis may spread from camels, and the lack of detailed epidemiological research of the disease in camels strongly calls for a check of the prevalence of the disease. Moreover, camel brucellosis should be included in national programs for the control and eradication of brucellosis in endemic nations. So, individuals working with these animals should be aware about the risk of camels as a source of brucellosis. Further detailed research involving different possible risk factors in camels, humans and other animals in a wider area is suggested and will allow an effective control program to be designed and help as a baseline for supplementary study.

\section{Acknowledgement}

The authors would like to acknowledge the valuable contribution of Prof. Elahe Tajbakhsh of Department of Microbiology, School of Basic Sciences, Shahrekord Branch, Islamic Azad University, Shahrekord, Iran, and Dr. Augustino A. Chengula of Sokoine University of Agriculture in Morogoro, Tanzania. Also the authors would like to thank all the staff at the Biotechnology Research Center of the Islamic Azad University of Shahrekord for their important technical and clinical support. This work was supported by the Islamic Azad University, Shahrekord Branch-Iran.

\section{REFERENCES}

1. Gwida MM, El-Gohary AH, Melzer F, Tomaso H, Rösler U, Wernery U, Wernery R, Elschner MC, Khan I, Eickhoff M, Schöner D, Neubauer H: Comparison of diagnostic tests for the detection of Brucella spp. in camel sera. BMC Research Notes 2011, 4:525.

2. Ghorbani A, Rabbani Khorasgani M, Zarkesh-Esfahani H, Sharifiyazdi H, Dehghan Kashani A, Emami H: Comparison of serology, culture, and PCR for detection of brucellosis in slaughtered camels in Iran. Comp Clin Pathol 2013, 22:913-917.

3. Abbasa B, Agab H: A review of camel brucellosis. Preventive Veterinary Medicine 2002, 55: 47-56.

4. Khamesipour F, Doosti A, Taheri H: Molecular Detection of Brucella spp. in the Semen, Testis and Blood Samples of Cattle and Sheep. Journal of Pure And Applied Microbiology 2013, 7 (Spl. Edn.): 495-500. 
5. Tilahun B, Bekana M, Belihu K, Zewdu E: Camel brucellosis and management practices in Jijiga and Babile districts, Eastern Ethiopia. Journal of Veterinary Medicine and Animal Health 2013, 5(3): 81-86.

6. Matović K, Ašanin Ružica, Radojičić Sonja, Lako B, Žarković A: Examination of sensitivity and specificity of some serological tests in diagnostics of bovine brucellosis, Acta Veterinaria (Beograd) 2008, 58( 5-6): 467-476.

7. Alshaikh MAA, Al-Haidary AI, Aljumaah RS, Mohammed OB, Al-Korashi MM, Omer SA, EINabi ARG, Hussein MF: First detection of Brucella abortus in camel serum in Saudi Arabia using the polymerase chain reaction. J Appl Anim Res 2007, 31:149-152.

8. Bricker BJ: PCR as a diagnostic tool for brucellosis. Vet Microbiol 2002, 90:435-46.

9. Sambrook J, Russell D: Molecular Cloning: a Laboratory Manual, 3rd edn. Cold Spring Harbor, NY: Cold Spring Harbor Laboratory, 2001.

10. Mirnejad R, Hosseini Doust R, Kachuei R, Mojtaba Mortazavi S, Khoobdel M, Ahamadi A: Simultaneous detection and differentiates of Brucella abortus and Brucella melitensis by combinatorial PCR. Asian Pacific Journal of Tropical Medicine 2012, 2012: 24-28.

11. Gwida MM, El-Gohary AH, Melzer F, Khan I, Rosler U, Neubauer H: Brucellosis in camels. Research in Veterinary Science 2012, 92: 351-355.

12. Abou-Eisha MJ: Brucellosis in camels and its relation to public health. Assiut Veterinary Medicine Journal 2000, 44: 54-64

13. Omer MK, Skjerve E, Holstad G, Woldehiwete Z: Prevalence of antibodies to Brucella spp. in cattle, sheep, goats, horses and camels in the State of Eritrea; influence of husbandry systems. J Infect 2000, 125: 447-453.

14. Gupta VK, Verma DK, Singh K, Kumari R, Singh SV, Vihan VS: Single-step PCR for detection of Brucella melitensis from tissue and blood of goats. Small Rumin Res 2006, 66:169-174.

15. Junaidu AU, Oboegbulem SI, Sharubutu GH, Daneji AI: Brucellosis in camels (Camelus dromedaries) slaughtered in Sokoto, northwestern Nigeria. Animal Production Research Advances 2006, 2: 158-160.

16. Ilhan Z, Aksakal A, Ekin IH, Gulhan T, Solmaz H, Erdenlig S: Comparison of culture and PCR for the detection of Brucella melitensis in blood and lymphoid tissues of serologically positive and negative slaughtered sheep. Appl Microbiol 2008, 46:301-306.

17. Ghanem MY, El-Khodery AS, Saad AA, Abdelkader HA, Heybe A, Musse AY: Seroprevalence of camel brucellosis (Camelus dromedarius) in Somaliland. Tropical Animal Health and Production 2009, 41: 1779-1786.

18. AL-Majali MA, AL-Qudah MK, AL-Tarazi AL, Rawashdeh FO: Risk factors associated with camel brucellosis in Jordan. Tropical Animal Health and Production 2008, 40: 193200.

19. Warsame I, Alemu S, Temesgen W, Molla W: Seroprevalence and Associated Risk Factors of Camel (Camelus dromedaries) Brucellosis in and Around Dire Dawa, Ethiopia. Global Veterinaria 2012, 8 (5): 480-483.

20. Yawoz M, Jaafar SE, Salih AI, Abdullah MH: A serological study of brucellosis in camels south of Kirkuk, Iraq. Iraqi Journal of Veterinary Sciences 2012, 26(2): 105-107.

21. Hamdy MER, Amin AS: Detection of Brucella Species in the Milk of Infected Cattle, Sheep, Goats and Camels by PCR. The Veterinary Journal 2002, 163: 299-305. 
22. Jelastopulu E, Bikas C, Petropoulos C, Leotsinidis M. Incidence of human brucellosis in a rural area in western Greece after the implementation of a vaccination programme against animal brucellosis. BMC Public Health 2008, 8: 241.

23. Azwai SM, Carter SD, Woldehiwet Z, MacMillan A: Camel Brucellosis: Evaluation of field sera by conventional serological tests and ELISA. Journal of Camel Practice and Research 2001, 8:185-193.

24. Abdel Moghney FRA: A preliminary study on brucellosis on camels at Behira province. Assuit University Bulletin Environmental Researche 2004, 7: 39-43.

25. Teshome H, Molla B, Tibbo M: A seroprevalence study of camel brucellosis in three camelrearing regions of Ethiopia. Trop Anim Health Prod 2003, 35: 381-389.

26. Omer MM, Abdelaziz AA, Abusalab MS, Ahmed MA: Survey of brucellosis among sheep, Goats, Camels and Cattle in Kassala Area, Eastern Sudan. J Anim Vet Adv 2007, 6:635-637.

27. Musa MT, Eisa MZM, El Sanousi EM, Abdel Wahab MB, Perrett L: Brucellosis in Camels (Camelus dromedarius) in Darfur, Western Sudan. J Comp Path 2008, 138: $151 \mathrm{e} 155$.

28. Dawood HA: Brucellosis in Camels (Camelus dromedorius) in the south province of Jordan. American Journal of Agricultural and Biological Sciences 2008, 3:623-626.

29. El-Boshy M, Abbas H, El-Khodery S, Osman S: Cytokine response and clinicopathological findings in Brucella infected camels (Camelus dromedarius). Veterinarni Medicina 2009, 54: 25-32.

30. Zewold SW, Haileselassie M: Seroprevalence of brucella infection in camel and its public health significance in selected districts of Afar region, Ethiopia. J Environ Occup Sci 2012, 1(2):91-98.

31. Radwan AI, Bekairi SJ, Mukayel AA, Albokmy AM, Prasad PVS, Azar FN, Coloyan ER: Control of Brucella melitensis infection in large camel herd in Saudi Arabia using antibiotherapy and vaccination with Rev.1 vaccine. Revue Scientifique et Technique de 1 Office International des Epizooties 1995, 14: 719-732.

\title{
MOLEKULARNA ISPITIVANJA PREVALENCIJE BRUCELLA ABORTUS I BRUCELLA MELITENSIS U UZORCIMA KRVI I LIMFNIH ČVOROVA ŽRTVOVANIH KAMILA METODOM LANČANE REAKCIJE POLIMERAZE (PCR) U IRANU
}

\author{
KHAMESIPOUR Faham, RAHIMI Ebrahim, SHAKERIAN Amir, DOOSTI Abbas, \\ MOMTAZ Hassan
}

Bruceloza je zoonoza koja se karakteriše smanjenom sposobnošću reprodukcije i abortusima kod nekoliko vrsta životinja i ljudi. Brucelozu kod kamila izazivaju Brucella abortus i Brucella melitensis. Standardne dijagnostičke tehnike kao što su izolacija na hranljivim podlogama i serološke reakcije nisu pouzdane i imaju značajna ograničenja. Da bi se to izbeglo, radi dokazivanja bruceloze kod 123 kamile, uptorebljena je osetljiva dijagnostička molekularna metoda: PCR. Rezultati su pokazali da je 11,38\% ispitanih uzoraka krvi i 13,01\% uzoraka limfnih čvorova bilo pozitivno na Brucella spp. U studiji, 
od ukupno 123 uzoraka krvi, 5 uzoraka (4,065\%) je bilo pozitivno na B. abortus, a 3 $(2,439 \%)$ na B. melitensis. Od ukupno 123 uzorka krvi, 4 uzorka $(2,252 \%)$ su bila pozitivna na B. abortus, a $3(1,626 \%)$ na B. melitensis. Najveća prevalencija je bila u grupi mladih životinja, a starije kamile su retko oboljevale. Veća je prevalencija ustanovljena kod ženki. Rezultati ukazuju da je PCR osetljiva metoda koja može da se koristi kao potvrdni test za dokazivanje bruceloze kod živih životinja uz minimalan rizik od infekcije laboratorijskog osoblja koje obavlja dijagnostiku. Dobijeni rezultati ukazuju da postoji neophodnost definisanja programa kontrole i iskorenjivanja bruceloze kamila. Istovremeno, rezultati ukazuju na pouzdanost PCR metode u dokazivanju Brucella spp bakterija, u uzorcima krvi i limfnih čvorova, što čini ovaj metod pogodnim za rutinsku dijagnostiku bruceloze. 